\begin{tabular}{|l|c|c|c|r|}
\hline $\begin{array}{l}\text { Cuadernos de Investigación Geográfica } \\
\text { Geographical Research Letters }\end{array}$ & 2017 & N $^{\circ} 43(2)$ & pp. 697-718 & $\begin{array}{r}\text { ISSN 0211-6820 } \\
\text { eISSN 1697-9540 }\end{array}$ \\
\hline
\end{tabular}

DOI: http://doi.org/10.18172/cig.3235

(C) Universidad de La Rioja

\title{
TIMING AND EXTENT OF LATE PLEISTOCENE GLACIATION IN THE ARID CENTRAL ANDES OF ARGENTINA AND CHILE $\left(22^{\circ}-41^{\circ} \mathrm{S}\right)$
}

\author{
J. ZECH ${ }^{*}$, C. TERRIZZANO ${ }^{2}$, E. GARCÍA-MORABITO ${ }^{2,3}$, H. VEIT $^{2}$, R. ZECH $^{2}$ \\ ${ }^{1}$ Max Planck Institute for the Science of Human History, \\ Kahlaische Strasse 10, 07745 Jena, Germany. \\ ${ }^{2}$ Institute of Geography, University of Bern, Hallerstrasse 12, 3012 Bern, Switzerland. \\ ${ }^{3}$ Instituto de Estudios Andinos "Don Pablo Groeber", Universidad de Buenos Aires - Conicet, \\ Buenos Aires, Argentina.
}

\begin{abstract}
The arid Central Andes are a key site to study changes in intensity and movement of the three main atmospheric circulation systems over South America: the South American Summer Monsoon (SASM), the Westerlies and the El Niño Southern Oscillation (ENSO). In this semi-arid to arid region glaciers are particularly sensitive to precipitation changes and thus the timing of past glaciation is strongly linked to changes in moisture supply. Surface exposure ages from study sites between $41^{\circ}$ and $22^{\circ} \mathrm{S}$ suggest that glaciers advanced: $\left.i\right)$ prior to the global Last Glacial Maximum ( $\mathrm{gLGM})$ at $\sim 40 \mathrm{ka}$ in the mid $\left(26^{\circ}\right.$ $\left.30^{\circ} \mathrm{S}\right)$ and southern Central Andes $\left(35^{\circ}-41^{\circ} \mathrm{S}\right)$, ii) in phase with the gLGM in the northern and southern Central Andes and iii) during the late-glacial in the northern Central Andes. Deglaciation started synchronous with the global rise in atmospheric $\mathrm{CO}_{2}$ concentration and increasing temperature starting at $\sim 18 \mathrm{ka}$. The pre-gLGM glacial advances likely document enhanced precipitation related to the Southern Westerlies, which shifted further to the North at that time than previosuly assumed. During the gLGM glacial advances were favored by decreased temperatures in combination with increased humidity due to a southward shifted Intertropical Convergence Zone (ITCZ) and SASM. During the late-glacial a substantial increase in moisture can be explained by enhanced upper tropospheric easterlies as response to an intensified SASM and sustained La Niña-like conditions over the eastern equatorial Pacific that lead to glacial advances in the northern Central Andes and the lake level highstand Tauca (18$14 \mathrm{ka}$ ) on the Altiplano. In the southernmost Central Andes at $39^{\circ}-41^{\circ} \mathrm{S}$, further north at $31^{\circ} \mathrm{S}$ and in the northernmost Central Andes at $22^{\circ} \mathrm{S}$ glacial remnants even point to precipitation driven glaciations older than $\sim 115 \mathrm{ka}$ and $260 \mathrm{ka}$.
\end{abstract}


Cronología y extensión de las glaciaciones pleistocenas tardías en los Andes Centrales áridos de Argentina y Chile $\left(22^{\circ}-41^{\circ} \mathrm{S}\right)$

RESUMEN. Los Andes Centrales áridos constituyen un lugar clave para el estudio de los cambios en la dinámica e intensidad de los tres sistemas principales de circulación atmosférica presentes en Sudamérica: los vientos monzones, los vientos del oeste y el fenómeno El Niño-Oscilación del Sur. Debido a la aridez, los glaciares de esta región son particularmente sensibles a variaciones en las precipitaciones, por lo que la cronología de las glaciaciones está fuertemente controlada por el suministro de humedad. Las edades de exposición obtenidas en morrenas en un transecto comprendido entre $41^{\circ}$ y $22^{\circ} \mathrm{S}$ de latitud indican avances glaciares que se sucedieron con anterioridad (unos 40 mil años BP) al Último Máximo Glaciar global (gLGM) para los Andes Centrales del sur $\left(35^{\circ}\right.$ $41^{\circ} \mathrm{S}$ ) y medios $\left(26^{\circ}-30^{\circ} \mathrm{S}\right)$. Avances en fase con el gLGM aparecen documentados en los Andes Centrales del sur y del norte, y durante el período Tardiglaciar en los Andes Centrales del norte. La deglaciación fue sincrónica a lo largo de todo el transecto y coincide con el incremento de los niveles de $\mathrm{CO}_{2}$ globales. Los avances previos al gLGM documentan un posible aumento en las precipitaciones asociado a una migración hacia el norte de los vientos del oeste, de mayor magnitud a la asumida hasta el momento. Asimismo, durante el gLGM los avances glaciares fueron favorecidos por una disminución de la temperatura que coincide con un aumento de la humedad debido a la migración hacia el sur de la Zona de Convergencia Intertropical y de los vientos monzones. La mayor disponibilidad de humedad durante el período Tardiglaciar podría explicarse por un aumento de los vientos del este en las capas altas de la tropósfera, como respuesta a una intensificación de los vientos monzones y condiciones tipo La Niña sostenidas en el tiempo sobre la zona oriental del Pacífico ecuatorial. Estas condiciones condujeron a las glaciaciones registradas en los Andes Centrales del norte en concordancia con estadios de nivel alto en los lagos del Altiplano (fase Tauca, 18-14 mil años). Los restos de morrenas conservados en los extremos sur $\left(39^{\circ}-41^{\circ} \mathrm{S}\right)$ y norte $\left(22^{\circ} \mathrm{S}\right)$ de los Andes Centrales, y a $31^{\circ} \mathrm{S}$ de latitud, indican a su vez avances glaciares anteriores a 115 y $260 \mathrm{ka}$, posiblemente controlados por las precipitaciones.

Keywords: glacial chronology, arid Central Andes of Argentina and Chile, ${ }^{10} \mathrm{Be}$ surface exposure dating, paleoclimate reconstruction.

Palabras clave: cronología glaciar, Andes Centrales áridos de Argentina y Chile, Datación de exposición de superficies mediante ${ }^{10} \mathrm{Be}$, reconstrucción paleoclimática.

Received: 7 February 2017

Accepted: 3 April 2017

*Corresponding author: Jana Zech, Max Planck Institute for the Science of Human History, Kahlaische Strasse 10, 07745 Jena, Germany. E-mail address: zech@shh.mpg.de 


\section{Introduction}

The mass balance of glaciers is particularly sensitive to changes in temperature and precipitation. Thus, reconstructing past climate from paleoglaciers yields important insights into timing and magnitude of climate changes regionally and into changes in the atmospheric circulation system and related climate dynamics. The Argentinean and Chilean Central Andes $\left(22^{\circ}-41^{\circ} \mathrm{S}\right)$ situated between the tropical and extratropical atmospheric circulation systems are a key area to study past climate changes in the Southern Hemisphere on orbital and millennial timescale. Today the Central Andes are ice limited due to the low amount of precipitation ( $<400$ mm, Bianchi and Yáñez, 1992; Haselton et al., 2002). However, pronounced geomorphological features like moraines record extensive glaciations in the past.

Establishing and correlating glacial chronologies along the arid Central Andes allows reconstructing primarily precipitation changes related to the dynamics of the three main atmospheric circulation systems over South America-the South American Summer Monsoon (SASM), the El Niño Southern Oscillation (ENSO) and the Westerlies. However, multiple questions remain regarding the influence and interplay between the tropical circulation system and the Westerlies in the core region of the arid Central Andes, the so-called Arid Diagonal (Fig. 1). In this review, we summarize previous research studies (Zech R. et al., 2007, 2008, 2009, 2010; Zech J. et al., 2009) about the late Pleistocene glaciation history and present new surface exposure ages $\left({ }^{10} \mathrm{Be}\right)$ along a N-S transect through the Central Argentinian and Chilean Andes between $41^{\circ}$ and $22^{\circ} \mathrm{S}$ and interpret them in terms of climate variability.

\section{Geographical Setting}

The Andes are the dominant landform in South America (Fig. 1). The mountain chain is roughly $9000 \mathrm{~km}$ long and up to $750 \mathrm{~km}$ wide. Peaks can exceed altitudes of $6000 \mathrm{~m}$. Ice caps and glaciers are present in the tropical and subtropical Andes north of $18^{\circ} \mathrm{S}$ and again south of $27^{\circ} \mathrm{S}$.

Between $\sim 18^{\circ} \mathrm{S}$ and $27^{\circ} \mathrm{S}$, lies the so-called Arid Diagonal (Ammann et al., 2001). This core region of the Andes separates the regions to the north where moisture is primarily provided by the tropical circulation system from regions in the south where precipitation is provided by the Westerlies. No glaciers exist today in the Arid Diagonal due to extreme aridity $(<100 \mathrm{~mm} / \mathrm{a})$ even though peak altitudes lie above the zero-degree isotherm (Ammann et al., 2001; Zech R. et al., 2009).

The Central Andes extend along a transitional zone where precipitation has a distinct maximum (>80\%) in the north (tropical and subtropical Andes), during austral summer associated with the South American Summer Monsoon (SASM) (Zhou and Lau, 1998; Garreaud et al., 2009) (Fig. 1). Between November and February, north-east trade winds transport moisture from the North Atlantic over the Amazon Basin. From there the South American Low Level Jet (SALLJ) flows southward along the Andean slope to the Gran Chaco basin. There the Chaco Low develops in the lower troposphere and the Bolivian High in the upper troposphere in response to strong insolation and convection. Ultimately, upper tropospheric easterlies, which intensify mutually with the Bolivian High, drag the 
moisture from the lowlands into the Eastern Cordillera and onto the Altiplano (Garreaud et al., 2003; Vuille and Keimig, 2004). The intensity and location of this precipitation regime is modulated by the position of the Intertropical Convergence Zone (ITCZ), North Atlantic sea surface temperature (SST) and ENSO (Vuille et al., 2000; Garreaud and Aceituno, 2001; Vuille and Keimig, 2004). During La Niña years, SST in the eastern equatorial Pacific (EEP) cools. This strengthens the subsidence and enhances the upper tropospheric easterlies dragging more moisture into the Andean range. In contrast, during El Niño years the SST of the EEP rises and leads to convection, which weakens the upper tropospheric easterlies and causes anomalously dry conditions in the Andean range.

South of the Arid Diagonal $\left(>27^{\circ} \mathrm{S}\right.$ ) precipitation mainly falls during austral winter and is related to the Southern Westerlies, which provide moisture from the Pacific. The storm tracks shift from $55-45^{\circ} \mathrm{S}$ to their northernmost position at about $30^{\circ} \mathrm{S}$ and cause wet conditions in the Andean Cordillera (Garreaud et al., 2009). The Southern Westerlies also affect regions east of the Andean divide as far north as $\sim 23-25^{\circ} \mathrm{S}$ when cold cut offs interact with warm and humid continental air, which generates large cloud cluster and
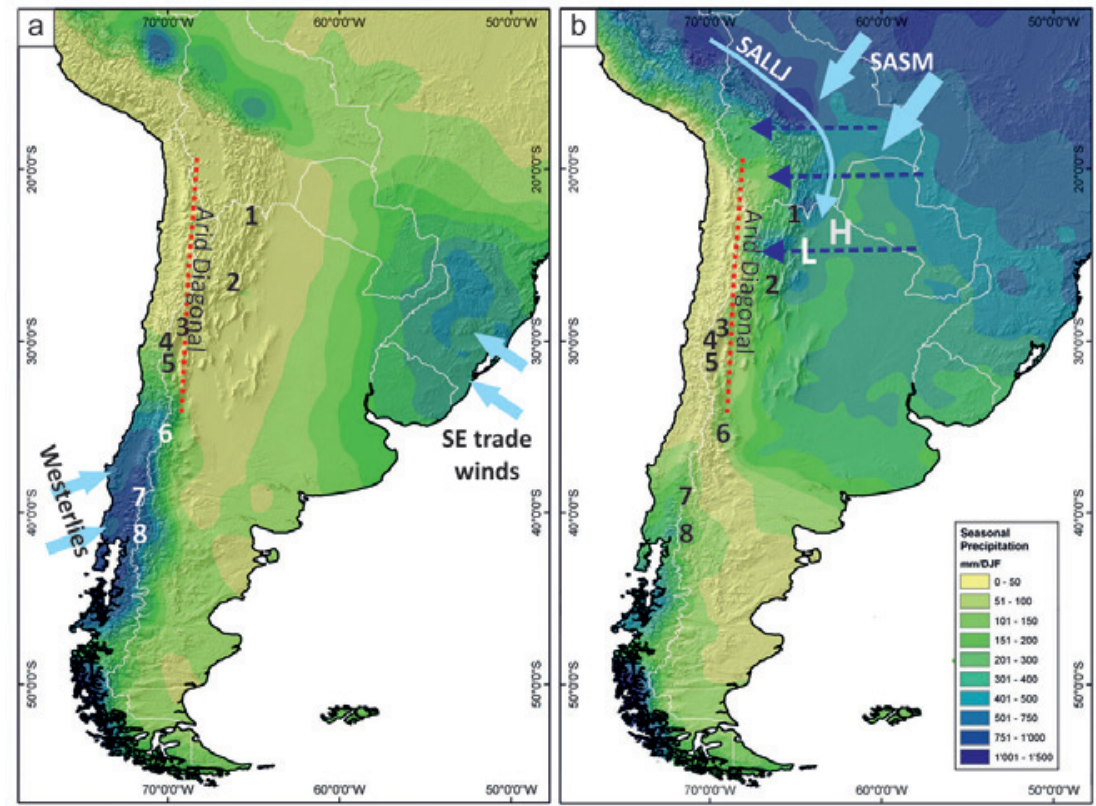

1 Tres Lagunas 2 Sierra de Quilmes 3 Valle Encierro 4 Cordon de Doña Rosa 5 Cerro Fredes 6 Las Leñas 7 Valle Rucachoroi 8 Bariloche

Figure 1. Location of research areas (numbers 1 to 8) and geographic setting in the Central

Andes. a) mean austral winter precipitation regimen (June-July-August), b) mean austral summer precipitation regimen (DJF, December-January-February). Light blue arrows indicate the main atmospheric circulation systems, the South American Summer Monsoon (SASM) and the South American Low Level Jet (SALLJ) from the North and the Westerlies from the South. Dotted blue arrows show the upper tropospheric easterlies. Note the location of the Arid Diagonal in dotted red lines., $L$ - Chaco Low, $H$ - Bolivian High. 
causes precipitation (Vuille and Ammann, 1997; Garreaud et al., 2009). Although the peak altitudes of the Andes drop from $<6000 \mathrm{~m}$ north of $35^{\circ} \mathrm{S}$ to only $<3000 \mathrm{~m}$ further south, they remain glaciated, because precipitation increases to $<2000 \mathrm{~mm} / \mathrm{a}$ at $40^{\circ} \mathrm{S}$ (Garreaud and Aceituno, 2007) and temperatures decrease.

\section{Material and Methods}

\subsection{Fieldwork}

Fieldwork included geomorphological mapping of the research area as well as documentation (photography, geographical position using a handheld GPS, and shielding by surrounding topography). For surface exposure dating $<0.5-1 \mathrm{~kg}$ of quartzite material was collected with hammer and chisel from sufficiently large and stable quartzite boulders from the stable top of the moraine ridges or glacio-morphological features with no signs of rock surface erosion in order to minimize the risk of too young exposure ages due to post-depositional processes, such as denudation, boulder exhumation, boulder toppling and rock surface erosion. When possible, we collected at least three samples on each moraine to identify outliers and avoid over or underestimations due to samplespecific effects (inheritance or post depositional instability). Details of field work and geomorphological mapping of the study sites can be found in the original publications (Zech R. et al., 2007, 2008, 2009, 2010; Zech J. et al., 2009).

\section{2. ${ }^{10}$ Be laboratory procedure and measurement}

Physical and chemical pre-treatment of samples was conducted at the University of Bern following well established standard procedures involving: (i) sample crushing and sieving (to a size fraction of 250-400 $\mu \mathrm{m}$ ), (ii) separating quartz from biotite and other magnetic minerals using a Frantz magnetic separator, (iii) three times rinsing of the sample with milliQ water as a first cleaning step, (iv) leaching of the sample with HCL (32\%) to remove all organic remains, (v) leaching with $\mathrm{HF}(4 \%)$ four times to dissolve all minerals except of quartz and to remove atmospheric ${ }^{10} \mathrm{Be}$ from the mineral surface (vi) addition of a ${ }^{9} \mathrm{Be}$ carrier $(\sim 300 \mu \mathrm{g})$ followed by total dissolution in $\mathrm{HF}(40 \%)$, (vii) beryllium extraction through anion and cation exchange column chromatography, (viii) $\mathrm{pH}$-sensitive precipitation and oxidation, and (ix) measuring the ${ }^{10} \mathrm{Be} /{ }^{9} \mathrm{Be}$ ratio at the ETH Zurich tandem AMS facility. Samples from Cordón de Doña Rosa, Bariloche, Cerro Fredes, El Encierro valley and Tres Lagunas were normalized to standard S555, with a nominal value of ${ }^{10} \mathrm{Be} /{ }^{9} \mathrm{Be}=95.5 \times 10^{-12}( \pm 2.5 \%)$. Samples from Las Leñas were normalized to standard S2007, with a nominal value of ${ }^{10} \mathrm{Be} /{ }^{9} \mathrm{Be}=30.8 \times 10^{-12}( \pm 2.5 \%$, Kubik and Christl, 2010). Samples from Nevados de Chusca (Sierra de Quilmes) and the Rucachoroi valley were normalized using both standards depending on the sample (see Table 1).

\subsection{Exposure age calculation and interpretation}

Exposure ages were calculated or re-calculated from previous publications of Zech R. et al. (2007, 2008, 2009, 2010), Zech J.et al. (2009) with the CRONUS Calc v.2.0 (http:// 
Zech et al.

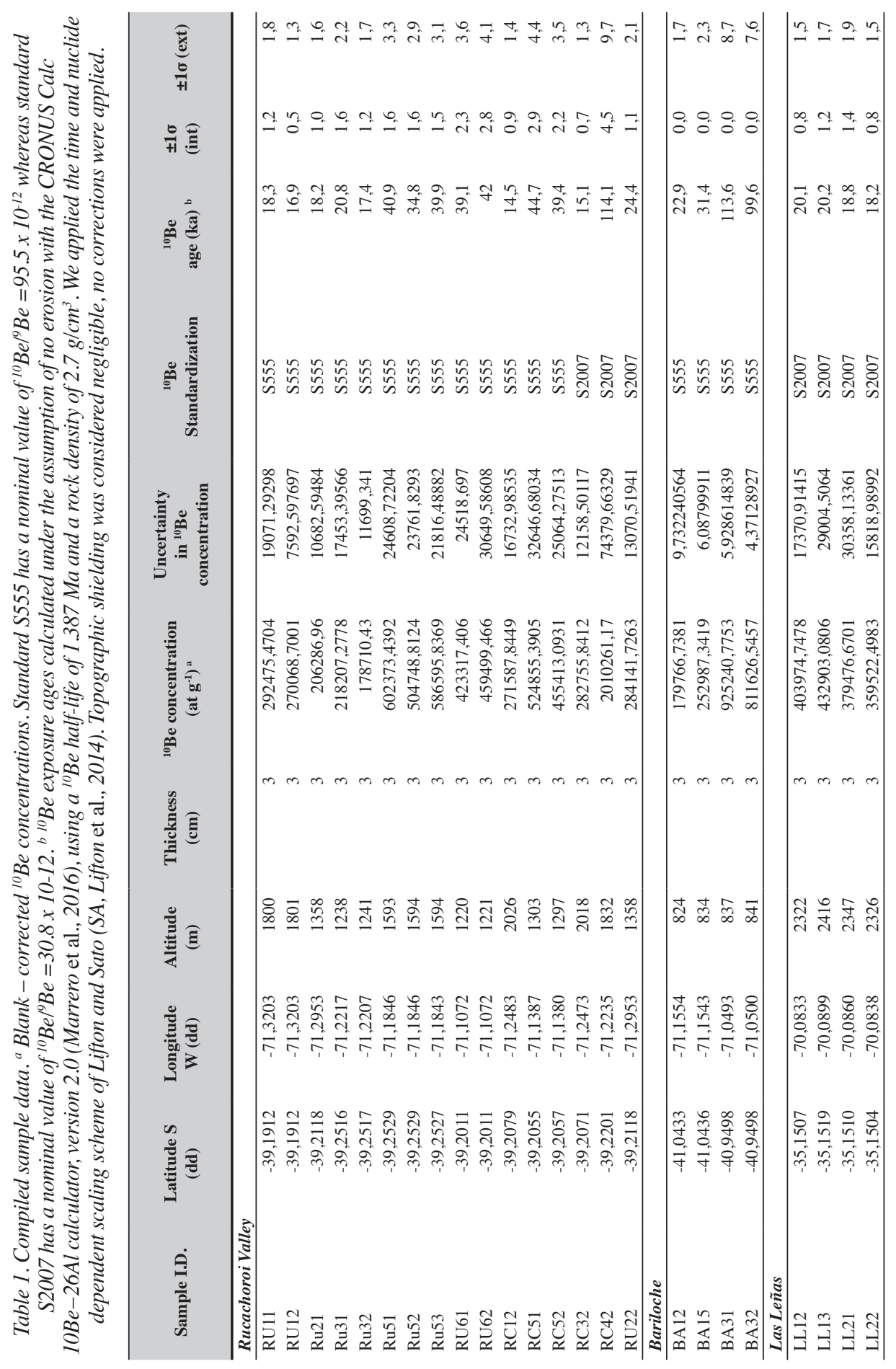


Timing and extent of late pleistocene glaciation in the arid Central Andes of Argentina and Chile $\left(22^{\circ}-41^{\circ} \mathrm{S}\right)$

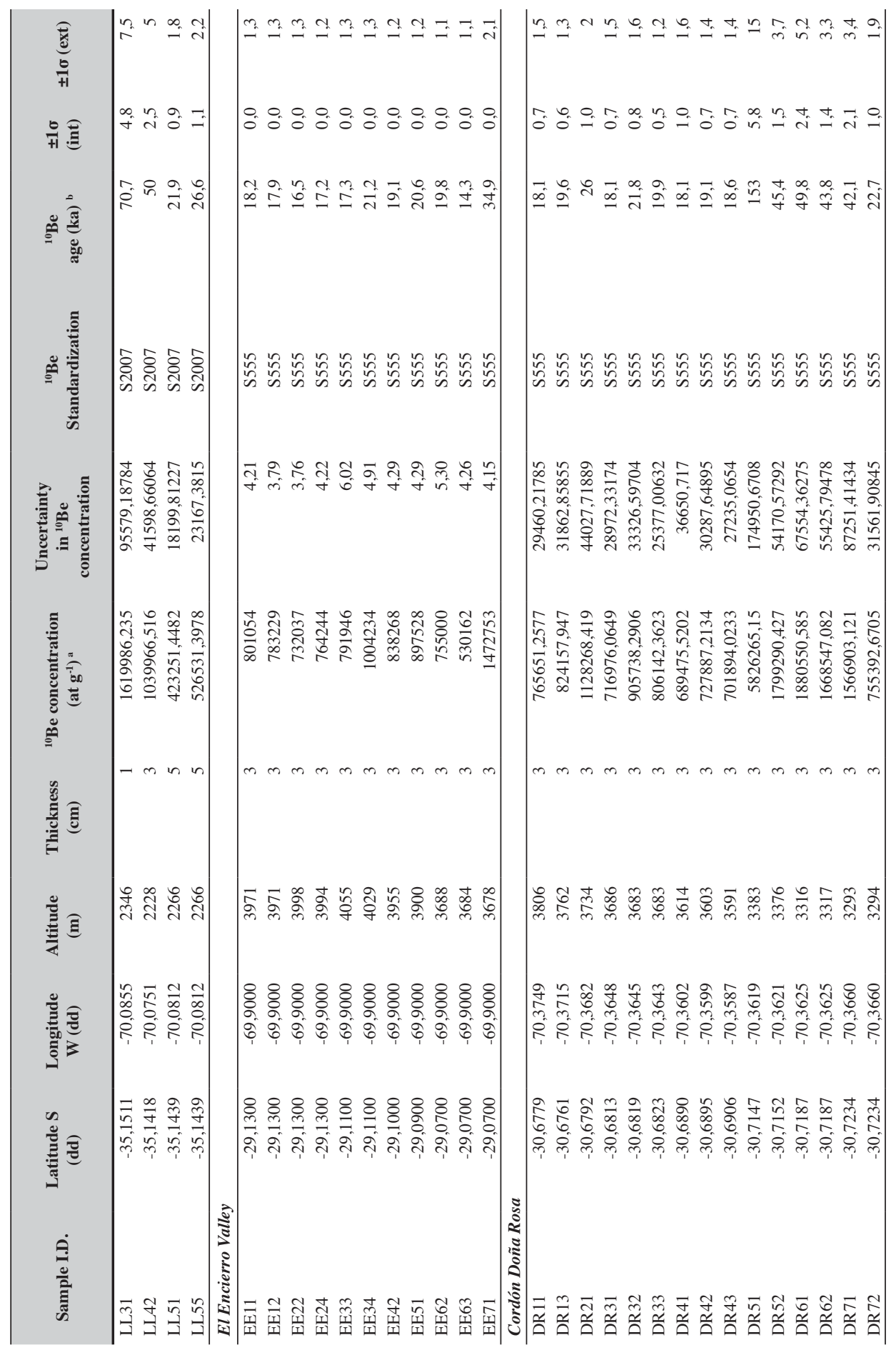




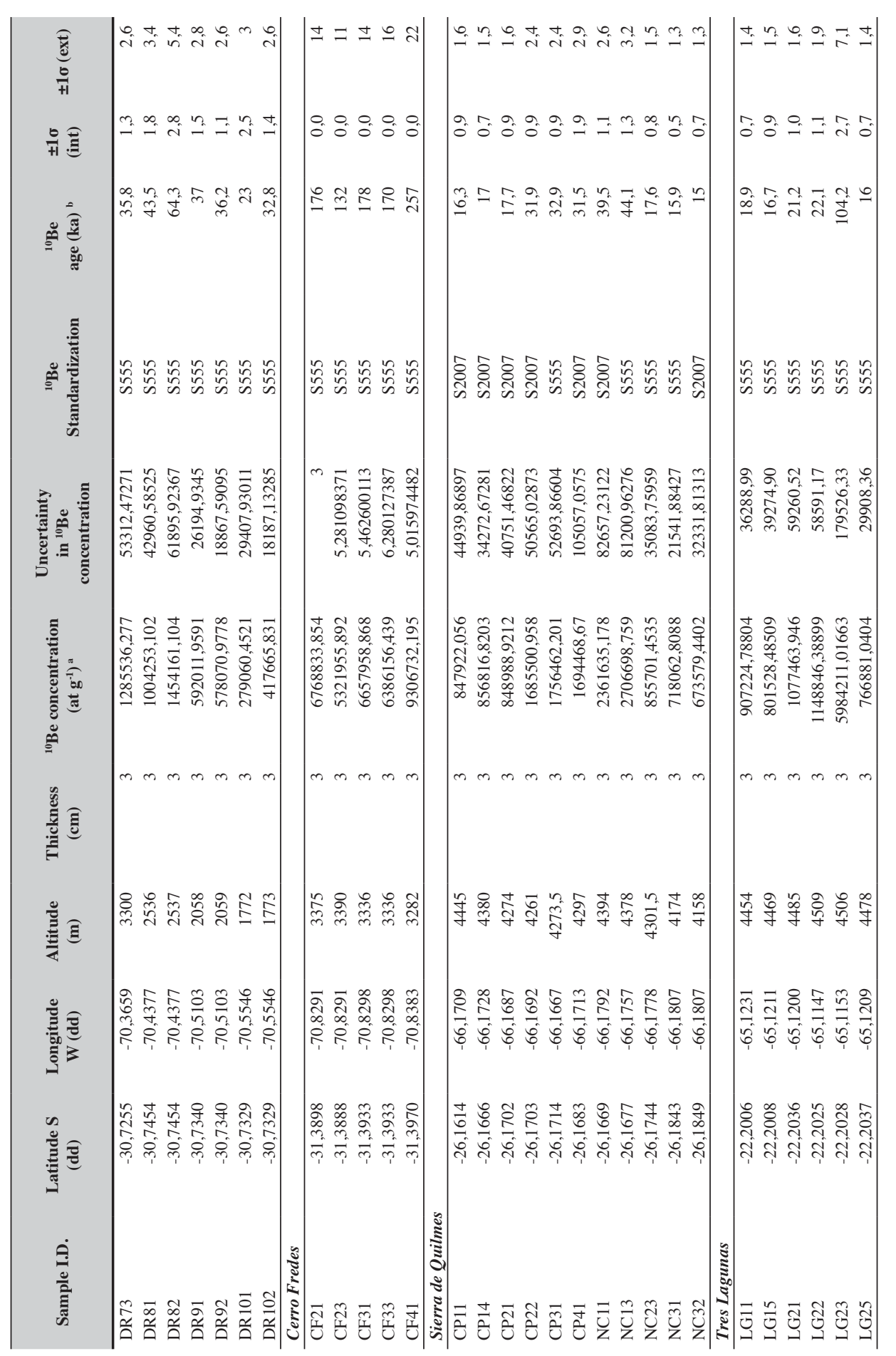




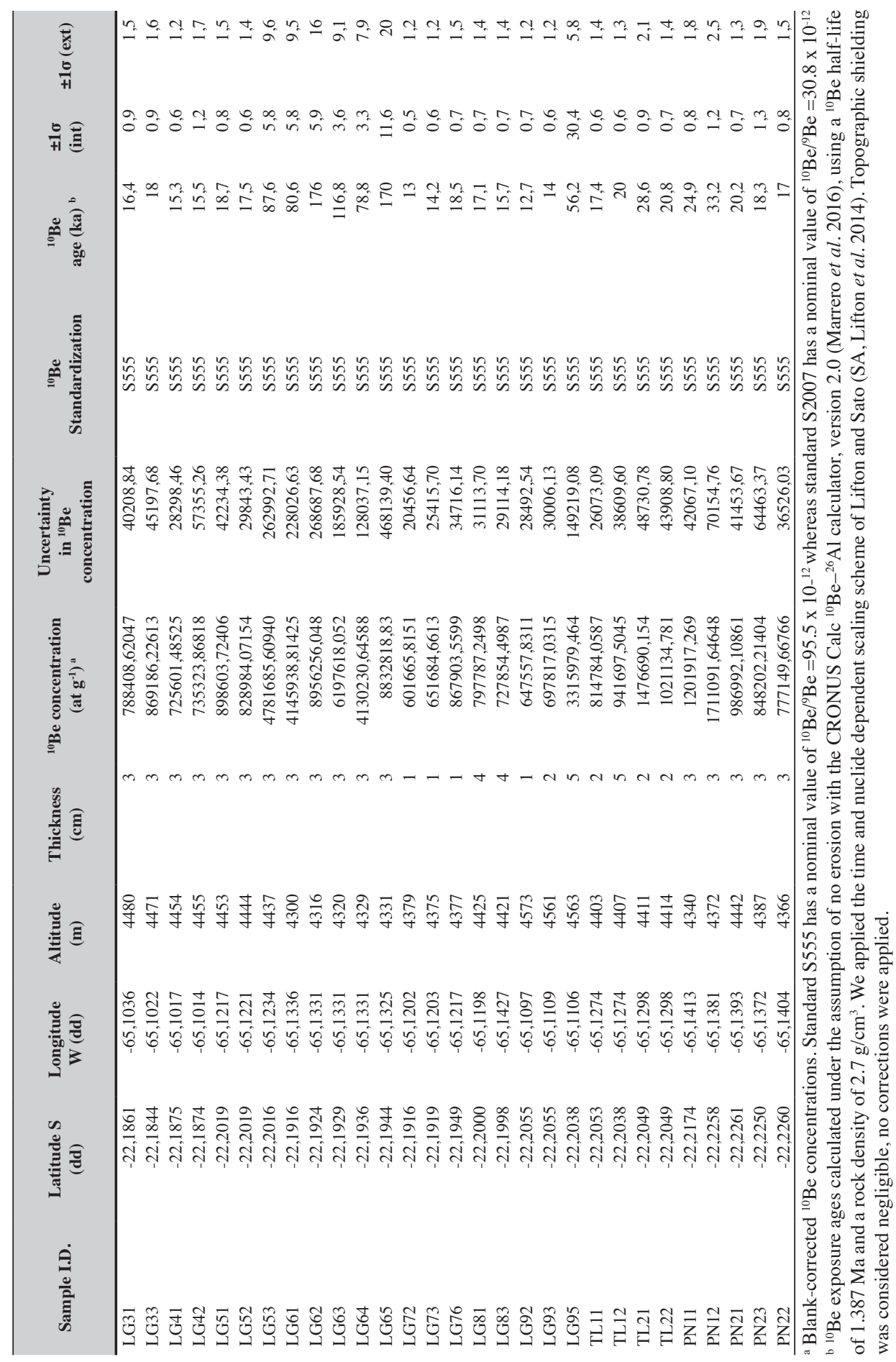


web1.ittc.ku.edu:8888/2.0/html/al-be/), described by Marrero et al. (2016), applying the nuclide and time dependent scaling model of Lifton and Sato (SA or LSD, Lifton et al., 2014) with a production rate of $3.92 \pm 0.31$ atoms $\mathrm{g}^{-1} \mathrm{yr}^{-1}$ (Phillips et al., 2016). We preferred to use this scaling model because it includes an updated geomagnetic and solar modulation framework, accounting for the effect of these factors on the cosmic-ray spectra. It also includes altitudinal scaling for separate nuclides (Lifton et al., 2014). CRONUS Calc uses a ${ }^{10} \mathrm{Be}$ half-life of $\sim 1.39 \mathrm{Ma}$ (Chmeleff et al., 2010; Korschinek et al., 2010).

Exposure ages were corrected for sample thickness. Topographic shielding was considered negligible and no corrections were applied (Table 1). We excluded shielding effects of vegetation and snow cover and considered negligible erosion as well as persistent arid conditions in the investigated areas of this review since the early Holocene result in minimal soil development and a scarce vegetation cover, so that obtained surface exposure ages represent minimum ages.

In principle, it is possible to find boulders with inherited cosmogenic ${ }^{10} \mathrm{Be}$ from a previous exposure history in a moraine ridge, which would provide an older than expected surface exposure age. However, the probability is assumed to be very low $(<3 \%)$ (Putkonen and Swanson, 2003; Heyman et al., 2011). Moraine boulders can experience post-depositional processes (e.g. denudation, boulder exhumation, boulder toppling and rock surface erosion) resulting in too young exposure ages as well. Except in cases where there are clear statistical or stratigraphical outliers, we followed the approach of the 'oldest age model' (Briner et al., 2005; Zech R. et al., 2005), according to which the oldest boulder is a minimum estimate for the moraine age and beginning of ice retreat. Sample details and surface exposure ages are compiled in Table 1.

\section{Glacial chronology}

\subsection{South of the Arid Diagonal $\left(41^{\circ}-29^{\circ} \mathrm{S}\right)$}

\subsubsection{Rucachoroi valley $\left(\sim 39^{\circ} \mathrm{S}\right)$ and Bariloche $\left(41^{\circ} \mathrm{S}\right)$}

In the Rucachoroi valley the maximum ice extent for the most extensive glacial advance is marked by the outermost moraine, which yielded a minimum exposure age of $44.7 \pm 4.4 \mathrm{ka}$ (Fig. 2). Further up valley an end moraine marks the position of the glacial front during the gLGM ( 26 ka, Peltier and Fairbanks, 2006; Clark et al., 2009), dated to $20.8 \pm 2.2 \mathrm{ka}$. Deglaciation of the valley started at about $18 \mathrm{ka}$, according to the minimum exposure age of $18.3 \pm 1.8$ (sample RU 11, Table 1, Fig. 2). However, note that on the cirque north of the main valley a minor late glacial advance is dated to $15.1 \pm 1.3 \mathrm{ka}$ which is in phase with the Tauca lake transgression phase on the Altiplano (18-14 ka, Placzek et al., 2011) and Heinrich I (Heinrich, 1988; Hemming, 2004). Also, a sample dated to $114.1 \pm 9.7 \mathrm{ka}$ may be documenting the oldest advance in this valley. Near Bariloche, at the confluence of the Nahuel Huapi glacial lake and the Limay river (Fig. 3 ), four exposure ages of two moraine remnants tentatively document glacial advances at $113.6 \pm 8.7 \mathrm{ka}$ and $31.4 \pm 2.3 \mathrm{ka}$, clearly predating the gLGM. 


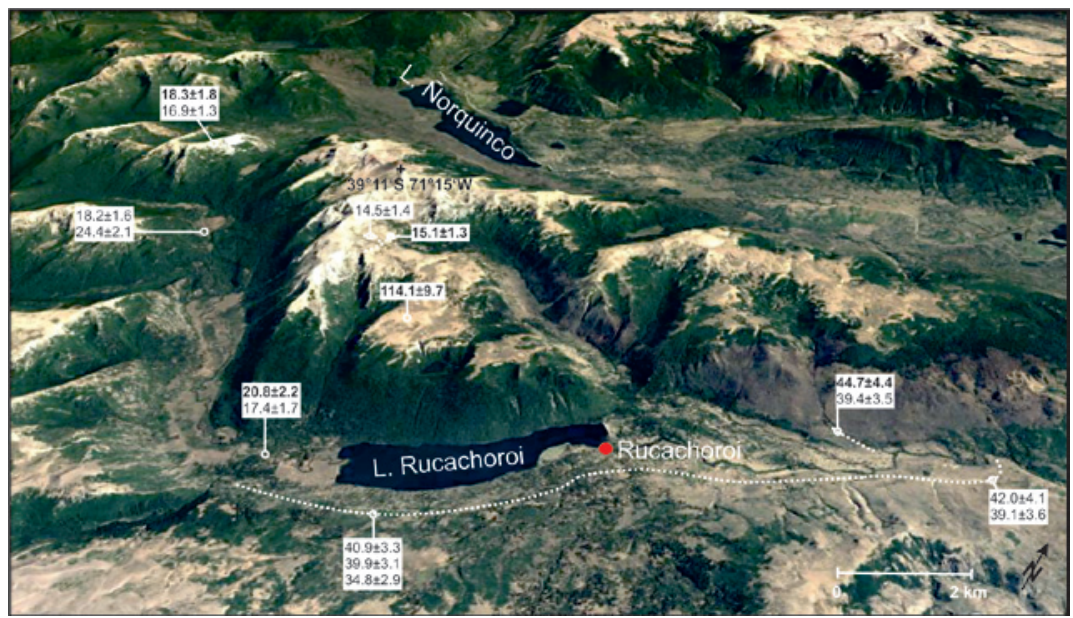

Figure 2. Google earth image of the Rucachoroi valley with the homonymous locality and lake. Circles indicate the sampling sites, White dashed lines show the crest of the frontal and lateral moraines of the local last glacial maximum advance in the valley. Bold ages show the interpreted deposition age. Shown ${ }^{10}$ Be surface exposure ages were re-calculated from Zech et al. (2008) applying the scaling system of Lifton and Sato (SA, Lifton et al., 2014).

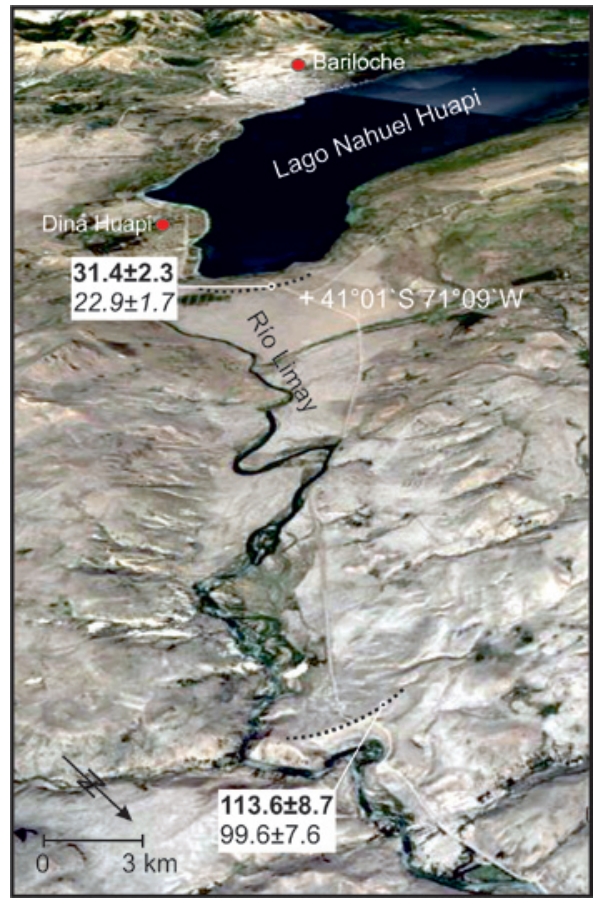

Figure 3. Google earth image of our study area near Bariloche. Black dashed lines: sampled frontal moraines. Bold ages show the interpreted deposition age ${ }^{10}$ Be surface exposure ages are calculated applying the scaling system of Lifton and Sato (SA, Lifton et al., 2014). 


\subsubsection{Las Leñas $\left(35^{\circ} \mathrm{S}\right)$}

At Las Leñas glaciers reached their maximum position most likely around $50.0 \pm 5.0 \mathrm{ka}$ (Fig. 4). Although this age has to be interpreted carefully, it documents the maximum ice extent for the most extensive glacial advance. Prominent, sharp crested lateral moraines document the most extensive advance during the gLGM at $21.9 \pm 1.8 \mathrm{ka}$. Glacier climate modelling results for those moraines (Wäger, 2009) suggest that enhanced precipitation in combination with a temperature reduction of -5 to $-8^{\circ} \mathrm{C}$ caused this gLGM advance. Deglaciation started at around $18.8 \pm 1.9 \mathrm{ka}$.

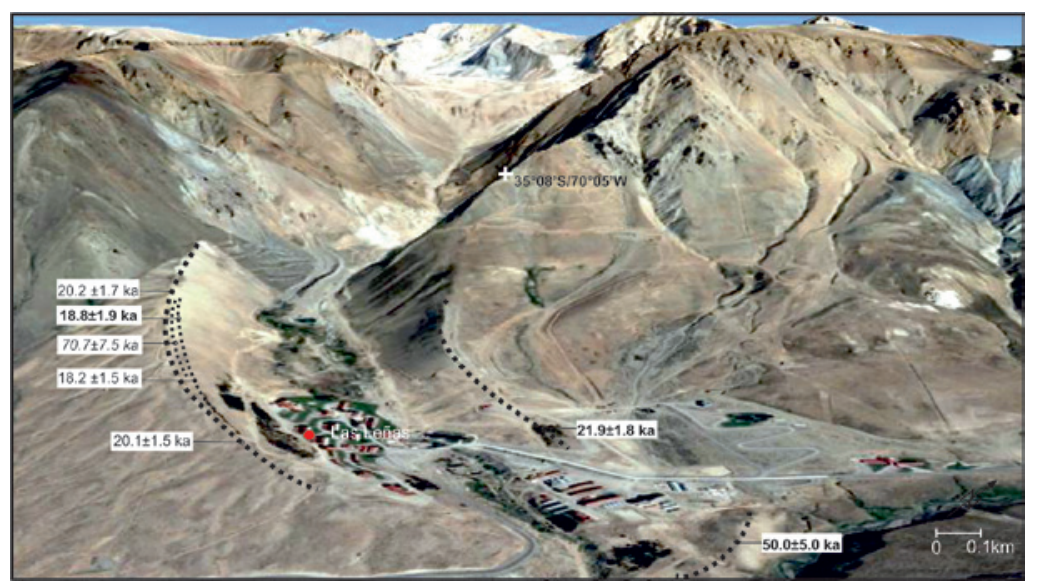

Figure 4. Google earth image of Las Leñas. Black dashed lines: sampled moraines. Bold ages show the interpreted deposition age. ${ }^{10}$ Be surface exposure ages are calculated applying the scaling system of Lifton and Sato (SA, Lifton et al., 2014).

\subsubsection{El Encierro valley (29 $\left.{ }^{\circ} \mathrm{S}\right)$, Cordón de Doña Rosa $\left(30^{\circ} \mathrm{S}\right)$ and Cerro Fredes $\left(\sim 31^{\circ} \mathrm{S}\right)$}

In El Encierro valley a well-preserved end moraine marks the maximum ice extent for the most extensive glacial advance dated to $34.9 \pm 2.1 \mathrm{ka}$ (Fig. 5). During the gLGM the valley was still covered by a glacier that reached its maximum extent before $21.2 \pm$ $1.3 \mathrm{ka}$. Deglaciation started shortly after at around $18 \mathrm{ka}$. Numerical modelling results from a glacier-climate study (Kull et al., 2002) indicate a temperature depression of $5.5^{\circ} \mathrm{C}$ and a precipitation increase to $550 \mathrm{~mm} / \mathrm{a}$ for the gLGM glacial advance. This suggests that increased humidity coupled to the temperature minima during the gLGM played an important role for the glacial advances in the southern and northern part of the Arid Diagonal.

In the Cordón de Doña Rosa $\left(30^{\circ} \mathrm{S}\right.$, Fig. 6) the maximum ice extent for the most extensive glacial advance is marked by a lateral moraine yielding a minimum ${ }^{10} \mathrm{Be}$ surface exposure age of $49.8 \pm 5.2 \mathrm{ka}$ in the main valley. In the adjacent valleys to the north the maximum ice extent is marked by lateral moraines yielding ${ }^{10} \mathrm{Be}$ surface exposure ages of $37.0 \pm 2.8 \mathrm{ka}$ and $32.8 \pm 2.6 \mathrm{ka}$. Due to the smaller catchment size we conclude that glaciers in the adjacent valleys most likely prevailed some $\sim 10 \mathrm{ka}$ longer then in the main valley. Only in the catchment of the main valley a gLGM glacial advance is dated to $21.8 \pm 1.6 \mathrm{ka}$. 


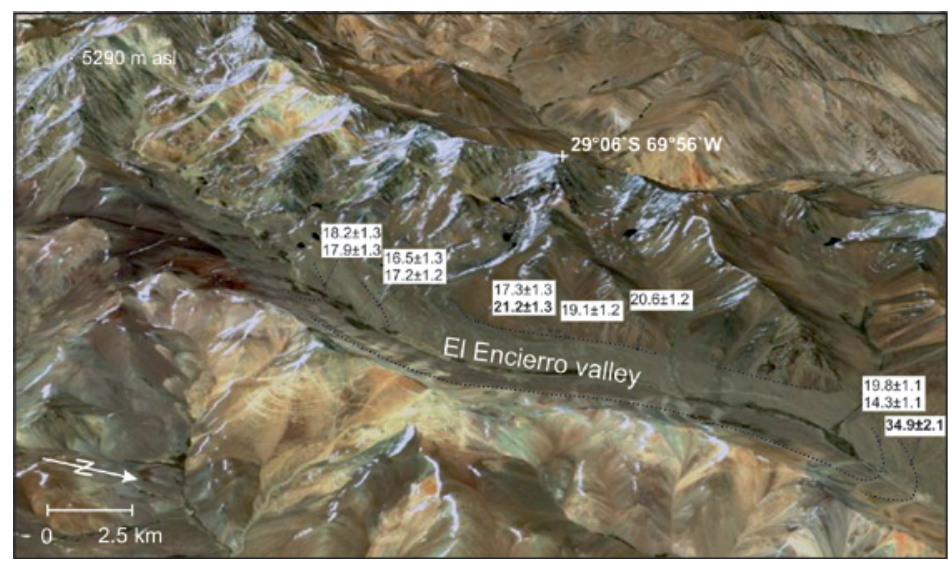

Figure 5. Google earth image of the El Encierro valley. Black dashed lines: sampled moraines. Bold ages show the interpreted deposition age. ${ }^{10} \mathrm{Be}$ surface exposure ages are re-calculated from Zech et al. (2008) applying the scaling system of Lifton and Sato (SA, Lifton et al., 2014).

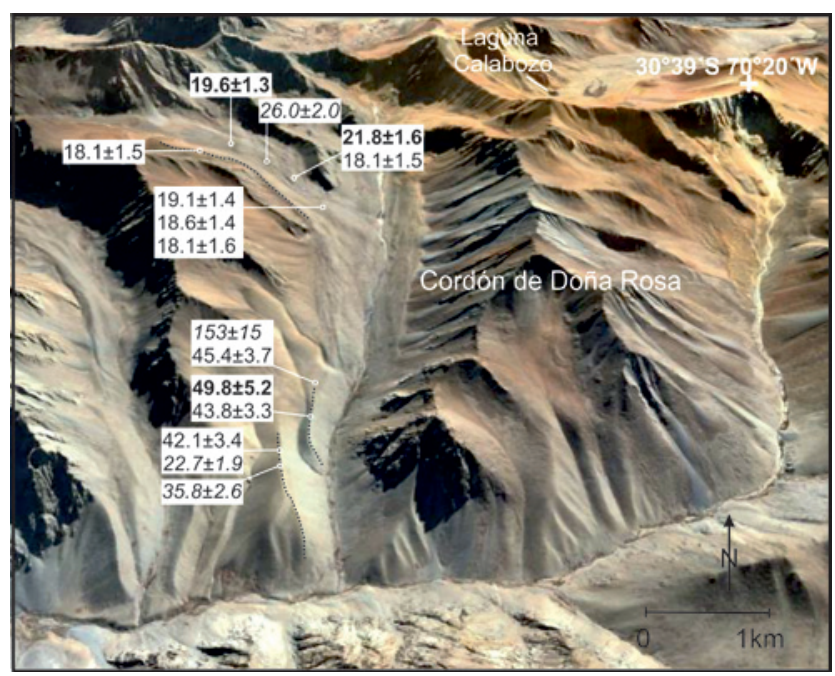

Figure 6. Google earth image of Cordón de Doña Rosa, Black dashed lines: main moraines, white circles indicate the collected samples and their obtained ages. ${ }^{10}$ Be surface exposure ages are re-calculated from Zech et al. (2008) applying the scaling system of Lifton and Sato (SA, Lifton et al., 2014).

Deglaciation started around $19.6 \pm 1.3 \mathrm{ka}$ in agreement with the global atmospheric $\mathrm{CO}_{2}$ rise. We consider the exposure age of $153 \pm 15 \mathrm{ka}$ as too old due to pre-exposure.

At Cerro Fredes $\left(31^{\circ} \mathrm{S}\right)$ the maximum ice extent for the most extensive glacial advance is documented by well-preserved moraines with ${ }^{10} \mathrm{Be}$ surface exposure ages of $257.0 \pm 22 \mathrm{ka}$ and $178.0 \pm 14 \mathrm{ka}$ (Fig. 7). Together with ages reported by Terrizzano et al. (2016) at $32^{\circ} \mathrm{S}$ on the Argentinian slope, these ages are so far the oldest evidence for a glaciation in the Central Andes dated with ${ }^{10} \mathrm{Be}$ SED. 


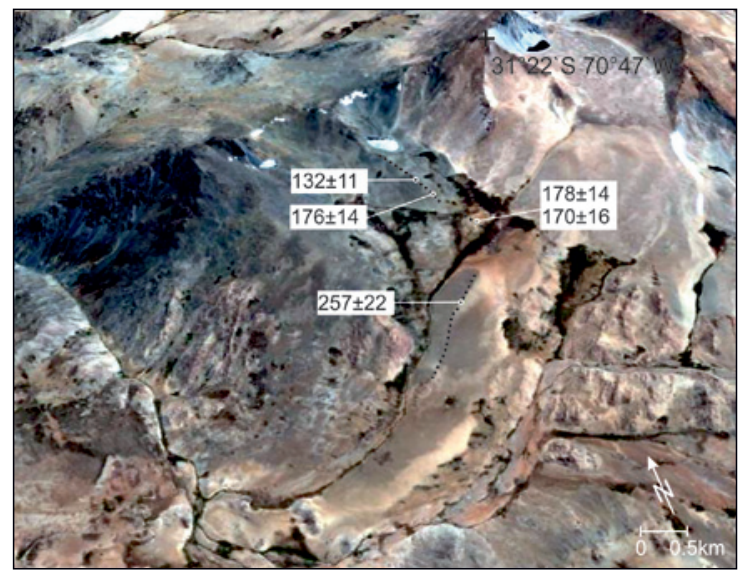

Figure 7. Google earth image of Cerro Fredes. Black dashed lines: sampled moraines. ${ }^{10}$ Be surface exposure ages are calculated applying the scaling system of Lifton and Sato (SA, Lifton et al., 2014).

\subsection{At the latitude of the Arid Diagonal $\left(26^{\circ}-22^{\circ} \mathrm{S}\right)$}

\subsubsection{Sierra de Quilmes $\left(\sim 26^{\circ} \mathrm{S}\right)$}

The Sierra de Quilmes $\left(\sim 26^{\circ} \mathrm{S}\right)$ is situated in the centre of the Arid Diagonal. Here, at the essentially distal end of the influence region of the SASM and the Southern Westerlies, precipitation is less than $400 \mathrm{~mm} / \mathrm{a}$ (Bianchi and Yáñez, 1992; Haselton et al., 2002) on the eastern side of the Andes and less than $100 \mathrm{~mm} / \mathrm{a}$ on the western side. An important increase in precipitation is thus necessary to provide glacial advances. However, well preserved glacial troughs from peaks of Cerro Pabellón ( 5000 m a.s.1.) and Nevados de Chusca ( $\sim 5400 \mathrm{~m}$ a.s.1.) reach down to $\sim 3800 \mathrm{~m}$ a.s.1. documenting massive glaciations in the past (Fig. 8). The most extensive glaciation in the Nevados de Chusca Valley is

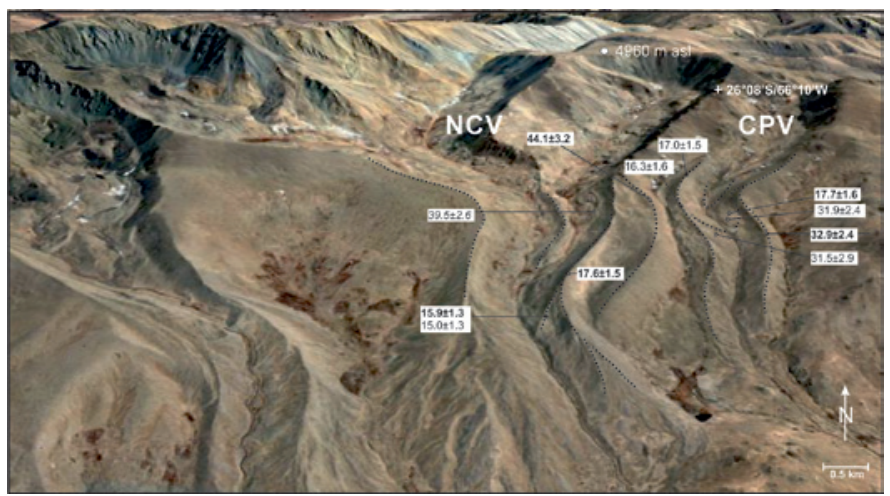

Figure 8. Google earth image of Sierra de Quilmes. Black dashed lines: sampled moraines. NCV: Nevados de Chusca Valley, CPV: Cerro Pabellón Valley. Bold ages show the interpreted deposition age. ${ }^{10}$ Be surface exposure ages are calculated applying the scaling system of Lifton and Sato (SA, Lifton et al., 2014). 
documented by a well-preserved moraine dating to $44.1 \pm 3.2 \mathrm{ka}$. Although the lower parts of the pronounced lateral moraines in the Nevados de Chusca Valley have not been sampled and dated, we can infer from the stratigraphic situation, that they must have been deposited between $44.1 \pm 3.2 \mathrm{ka}$ and $17.6 \pm 1.5 \mathrm{ka}$. Deglaciation started at $17.6 \pm 1.5 \mathrm{ka}$ in phase with the global atmospheric $\mathrm{CO}_{2}$ rise after $18 \mathrm{ka}$ interrupted only by a minor re-advance at around $15.9 \pm 1.3 \mathrm{ka}$ synchronous with the lake transgression phase Tauca (Placzek et al., 2011). In the Cerro Pabellón Valley the maximum ice extent is dated to $32.9 \pm 2.4 \mathrm{ka}$. Deglaciation started around $17.7 \pm 1.6 \mathrm{ka}$. Catchment size (Nevados de Chusca Valley: $\sim 21 \mathrm{~km}^{2}$ vs. Cerro Pabellón Valley: $\sim 3.6 \mathrm{~km}^{2}$ ) and altitude differences (Nevados de Chusca Valley: 5400m a.s.l.vs. Cerro Pabellón Valley: 5000 m a.s.1.) between both valleys can help to explain the different preservation of the maximum ice extent predating the gLGM and the late-glacial glacial advances.

\subsubsection{Tres Lagunas $\left(\sim 22^{\circ} \mathrm{S}\right)$}

The Tres Lagunas site and the adjacent valley of Peña Negra (Fig. 9) are located in the Sierra de Santa Victoria in NW Argentina, which forms the boundary between the eastern slope of the Andes to the east and the Altiplano/Puna plateau ( $\sim 3500 \mathrm{~m}$ a.s.l.)

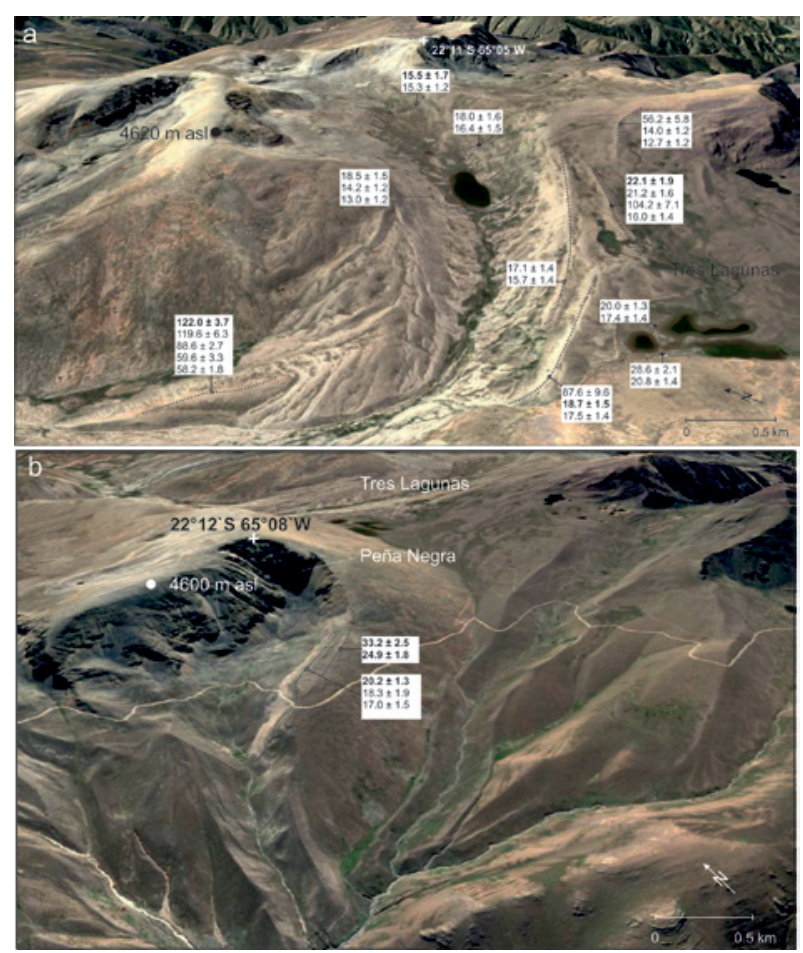

Figure 9. Google earth image of Tres Lagunas (a) and Peña Negra (b). Black dashed lines: sampled moraines. Bold ages show the interpreted deposition age. ${ }^{10}$ Be surface exposure ages are re-calculated from Zech et al. (2009a) applying the scaling system of Lifton and Sato (SA, Lifton et al., 2014). 
to the west. The oldest and most extensive glaciation occurred around $122.0 \pm 3.7 \mathrm{ka}$ and coincides most likely with the Ouki lake transgression phase (120-95 ka) on the Altiplano (Placzek et al., 2011). A second distinct glaciation occurred at $22.1 \pm 1.9 \mathrm{ka}$ in phase with the lake transgression phase Sajsi (24-20 ka, Placzek et al., 2011) and the temperature minimum during the gLGM. Deglaciation started at around $18.7 \pm 1.5 \mathrm{ka}$ in phase with the global rise in atmospheric $\mathrm{CO}_{2}$. High up in the catchment of Tres Lagunas site ( $4500 \mathrm{~m}$ a.s.1.), a small glacial readvance is dated to $15.5 \pm 1.7 \mathrm{ka}$ in phase with the Tauca lake transgression phase on the Altiplano (Placzek et al., 2011). At Peña Negra the maximum ice extent is documented by a sharp crested lateral moraine dating to $24.9 \pm 1.8 \mathrm{ka}$ and $33.2 \pm 2.5 \mathrm{ka}$. We tentatively suggest that this moraine correlates with the lateral moraines deposited during the gLGM at Tres Lagunas site. The inner lateral moraine was deposited at around $20.2 \pm 1.3 \mathrm{ka}$. The steeper valley morphology of the Peña Negra Valley might explain the observed minor age differences.

\section{Discussion}

Studies on the timing of glaciation (Zech R. et al., 2008; Blard et al., 2009; Rodbell et al., 2009; Zech J. et al. 2009; May et al., 2011) and glacier-mass balance modelling (Kull et al., 2008; Blard et al., 2009) highlight the importance of precipitation for glacial advances in the semi-arid Central Andes. The oldest glacial advances, dated to $\sim 115 \mathrm{ka}$ and $\sim 260 \mathrm{ka}$, are recorded south of and in the Arid Diagonal. The lack of information about wet or dry climate phases so far back in time prevents us to make further interpretations in terms of climate variability, although such ages may point to precipitation driven glaciations during Marine Iostope Stages (MIS) 8, 6 and in phase with the Ouki wet phase during MIS 5.

Glacial features from $41^{\circ} \mathrm{S}$ (Bariloche) to the north in the Ruchachoroi valley, Cordón de Doña Rosa, El Encierro valley, and even as far north as $26^{\circ} \mathrm{S}$ (Sierra de Quilmes) document that maximum ice extent for the most extensive glacial advance occurred as early as $40 \mathrm{ka}$ (MIS 3) both west and east of the Andean divide arguing for wetter conditions before the gLGM. This agrees with records of Laguna Tagua Tagua, Central Chile documenting increased winter precipitation between $~ 40-33$ ka (ValeroGarcés et al., 2005). Riquelme et al. (2011) reported radiocarbon ages from the Turbio Valley, Chile $\left(30^{\circ} \mathrm{S}\right)$, documenting an extensive glaciation between 37-27 cal. ka BP. Piedmont glaciers in the Chilean Lake District $\left(\sim 40^{\circ} \mathrm{S}\right.$, Lowell et al., 1995; Denton et al., 1999) and in the Andes of Mendoza ( $33^{\circ} \mathrm{S}$, Espizua, 2004, and $32^{\circ} \mathrm{S}$, Moreiras et al., 2016), reached maxima already at $\sim 40-35 \mathrm{ka}$ as well. We argue that in the semi-arid Central Andes glacial advances at $\sim 40 \mathrm{ka}$ reflect increased winter precipitation attributed to a stronger influence of the Southern Westerlies and more frequent cut offs. Enhanced Southern Westerlies and a stronger Antarctic circumpolar current are, for example, reflected by cooler SST in the SE Pacific (Kaiser et al., 2005, 2008). An increased influence of the Southern Westerlies on the hydrological conditions in regions as far as $26^{\circ} \mathrm{S}$ has also been reported from the Raraku Lake on Easter Island (SE Pacific, $27^{\circ} \mathrm{S}$, Sáez et al., 2009). There, higher lake levels dominated sedimentation between 34 and 28 cal. ka BP. Additionally, MIS 3 austral winter insolation at $30^{\circ} \mathrm{S}$ was maximal (Berger 
and Loutre, 1991), favouring more humid tropical air in the upper troposphere over the arid Andes. The interaction between cold cut offs coming from the Pacific and warmer, humid air over the continent could thus have generated more snowfall even east of the Andean divide. During austral summer, on the other hand, insolation was minimal and may have favoured cooler summer temperatures and reduced ablation.

The southern and northern Central Andes also document glacial advances in phase with gLGM. Glaciers advanced between 26-20 ka contemporaneous with lake level highstands recorded in the Uyuni (Baker et al., 2001) and Poopo Basin (paleolake Sajsi 24-20.5 ka, Placzek et al., 2006, 2011) in response to increased precipitation by an intensified SASM. Humid conditions were also reported for this period off shore Chile, $33^{\circ} \mathrm{S}$ (Lamy, 1999), in Laguna Tagua Tagua (Chile, 34³0’S, Valero Garcés et al., 2005) and in eolian sequences in Argentina ( $34^{\circ} \mathrm{S}$, Tripaldi and Forman, 2016). Maximum austral summer insolation at $30^{\circ} \mathrm{S}$ (Berger and Loutre, 1991) favoured a southward position of the ITCZ and was conducive for an intensification of the SASM and the upper tropospheric easterlies, so that a combination of globally lower temperatures and insolation minima and more humid conditions seem to have been responsible for glacial advances during the gLGM between $22^{\circ}$ and $39^{\circ} \mathrm{S}$. Enhanced precipitation during this period, however, has also been explained by a northward shift of the Southern Westerlies, which likely still provided additional precipitation for the gLGM advance in the arid Central Andes (Lamy et al., 1999; Kaiser et al., 2005; Maldonado et al., 2005; Valero-Garcés et al., 2005; Kaiser et $a l ., 2008)$, so that the Southern Central Andes likely received precipitation over the whole year during the gLGM. Furthermore, glacial advances attributed to lower temperatures and increased monsoonal precipitation in phase with the gLGM have also been reported north of the Arid Diagonal (May et al., 2011; Smith et al., 2011; Farber et al., 2005).

Deglaciation started along the whole transect at $\sim 18 \mathrm{ka}$, synchronous with the global atmospheric $\mathrm{CO}_{2}$ rise and thus increasing temperatures (Shakun et al., 2015). Advances are also documented during the late-glacial (here referred to as the period between 18-12 ka) at $\sim 16 \mathrm{ka}$ in the El Encierro valley, the Sierra de Quilmes and Tres Lagunas $\left(29^{\circ}-22^{\circ} \mathrm{S}\right)$ coinciding with a massive lake transgression phase recorded on the Altiplano (Placzek et al.,2011) and increased discharge of Río Lluta in northern Chile (Veit et al., 2016), implying an increase in precipitation during this time. Further south in the Rucachoroi valley $\left(39^{\circ} \mathrm{S}\right)$ a late-glacial glacier is still preserved at $\sim 15 \mathrm{ka}$. More age control is necessary in order to definitely explain this glacial advance, since topography and the northward exposure of the hill slope might have played a pivotal role. Extensive glacial advances during the lateglacial occurred also further north $\left(\sim 15\right.$ and $\left.22^{\circ} \mathrm{S}\right)$ in the eastern Cordillera of Argentina and Bolivia. Glaciers advanced before $\sim 14 \mathrm{ka}$ and $\sim 12 \mathrm{ka}$ (Clapperton et al., 1997; Clayton and Clapperton, 1997; Zreda et al., 2001; Blard et al., 2009; Zech R. et al., 2007, 2008, 2009; Zech J. et al. 2009; May et al., 2011) in phase with the Tauca (18.1-14.1 ka) and Coipasa (12.8-11.4 ka) lake transgression phases on the Altiplano, respectively (Clapperton et al., 1997; Clayton and Clapperton, 1997; Placzek et al., 2006, 2011). These two major lake expansions are part of the Central Andean Pluvial Event (CAPE, 18-8 ka) (Latorre et al., 2006; Quade et al., 2008), a regional wet phase that impacted regions between $10-26^{\circ} \mathrm{S}$. We explain the late-glacial advances recorded in the semi-arid Central Andes by enhanced humidity due to a southward shift of the ITCZ in response to northern hemispheric cooling 
during Heinrich I (Heinrich, 1988, Hemming, 2004) and lower temperatures in the eastern equatorial Pacific (Kienast et al., 2006; Bova et al., 2015) favoring La Niña like conditions bringing more moisture southward. Although south of $30^{\circ} \mathrm{S}$ the control of the SASM and La Niña-like conditions on late-glacial advances have not been revealed so far, glacial deposits of this age in the Rucachoroi valley could tentatively indicate an influence as far south as $39^{\circ} \mathrm{S}$.

\section{Conclusions}

In the arid Central Andes glaciers are very sensitive to changes in the precipitation regime. Our study shows that glaciations in this region were controlled by latitudinal shifts and intensity changes of the moisture sources, i.e. the tropical circulation system (SASM and ENSO) and the Southern Westerlies.

The oldest dated glaciations in the El Encierro valley probably correspond to global MIS 8 and 6. Glaciations at the southernmost (Rucachoroi valley and Bariloche) and northernmost (Tres Lagunas) sites studied in this work are in phase with the Ouki wet phase on the Altiplano. We argue that these old glaciations may also be moisture driven.

The maximum ice extent for the most extensive glacial advance predating the gLGM maximum during MIS 3 is present in the mid $\left(26^{\circ}-30^{\circ} \mathrm{S}\right)$ and southern Central Andes $\left(35^{\circ}-41^{\circ} \mathrm{S}\right)$, probably in response to an increased influence of the northward shifted and intensified Southern Westerlies and higher cut off frequency that interacted with the humid air over the continent generating large cloud cluster and increasing austral winter precipitation. This advance highlights the importance of the Southern Westerlies for glacial advances as far north as $26^{\circ} \mathrm{S}$.

Glaciers advanced again in phase with the gLGM at 26-20 ka. This time, however, due to lower temperatures and sufficient humidity provided over the whole year by both the Southern Westerlies and the SASM. The gLGM advance coincides with similar advances further north in NW Argentina, Bolivia and Peru, and with the Sajsi (24.5-20 ka) lake transgression phase on the Altiplano. A global rise in $\mathrm{CO}_{2}$ and subsequent increase in global temperatures lead to deglaciation across the whole arid Central Andes, starting at $\sim 18 \mathrm{ka}$. La Niña-like conditions and the intensified SASM enhanced the upper tropospheric easterlies and provided sufficient moisture for the massive late-glacial advance recorded in the northernmost part of the transect presented here and also tentatively as south as $39^{\circ} \mathrm{S}$.

\section{Acknowledgements}

We thank Anina Schmidhauser and Christoph Bächtiger for helping with fieldwork and laboratory analyses. J.Z. thanks Thomas Nägler and Igor Villa for providing laboratory facilities at the Institute of Geology, University of Bern. For helpful discussions and local logistic support we thank Grupo Yavi de Investigaciones Científicas, especially Liliana Lupo and Julio Kuhlemeier. This work was financially supported by the Swiss National Fund (Project 200020-113461/1). The authors thank Jesús Ruiz Fernández and an anonymous reviewer for the helpful feedback. 


\section{References}

Ammann C., Jenny, B., Kammer, K., Messerli, B. 2001. Late Quaternary Glacier response to humidity changes in the arid Andes of Chile (18-29'S). Palaeogeography, Palaeoclimatology, Palaeoecology 172, 313-326. http://doi.org/10.1016/S0031-0182(01)00306-6.

Baker, P.A., Rigsby, C.A., Seltzer, G.O., Fritz, S.C., Lowenstein, T.K., Bacher, N.P., Veliz, C. 2001. Tropical climate changes at millenial and orbital timescales on the Bolivian Altiplano. Nature 409, 698-701. http://doi.org/10.1038/35055524.

Berger,A.,Loutre,M.F. 1991. Insolation values for the climate of the last 10 million years. Quaternary Sciences Reviews 10 (4), 297-317. http://doi.org/10.1016/0277-3791(91)90033-Q.

Bianchi, A.R., Yáñez, C.E. 1992. Las Precipitaciones en el Noroeste Argentino. Instituto Nacional de Tecnología Agropecuaria (INTA), Argentina.

Blard, P.-H., Lave, J., Farley, K.A., Fornari, M., Jimenez, N., Ramirez,V. 2009. Late local glacial maximum in the Central Altiplano triggered by cold and locally-wet conditions during the paleolake Tauca episode (17-15 ka, Heinrich 1). Quaternary Science Reviews 27-28, 34143427. http://doi.org/10.1016/j.quascirev.2009.09.25.

Bova, S.C., Herbert, T., Rosenthal, Y., Kalansky, J., Altabet, M., Chazen, C., Mojarro, A., Zech, J. 2015. Links between eastern equatorial Pacific stratification and atmospheric $\mathrm{CO}_{2}$ rise during the last deglaciation. Paleoceanography 30, 11, 1407-1424. http://doi.org/10.1002/2015PA002816.

Briner, J.P., Kaufman, D.S., Manley, W.F., Finkel, R.C., Caffee, M.W. 2005. Cosmogenic exposure dating of late Pleistocene moraine stabilization in Alaska. Geological Society of America Bulletin 117, 1108-1120.

Chmeleff, J., von Blanckenburg, F., Kossert, K., Jakob, D. 2010. Determination of the ${ }^{10}$ Be half-life by multicollector ICP-MS and liquid scintillation counting. Nuclear Instruments and Methods in Physics Research Section B: Beam Interactions with Materials and Atoms 268 (2), 192-199. http://doi.org/10.1016/j.nimb.2009.09.012.

Clapperton, C.M., Clayton, J.D., Benn, D.I., Marden, C.J., Argollo, J. 1997. Late Quaternary glacier advances and paleolake highstands in the Bolivian Altiplano. Quaternary International 38-39, 49-59. http://doi.org/10.1016/S1040-6182(96)00020-1.

Clark, P.U., Dyke, A.S., Shakun, J.D., Carlson, A.E., Clark, J., Wohlfarth, B., Mitrovica, J.X., Hostetler, S.W., McCabe, A.M. 2009. The Last Glacial Maximum. Science 325, 710.

Clayton, J.D., Clapperton, C.M. 1997. Broad synchrony of a Late-Glacial glacier advance and the highstand of Palaeolake Tauca in the Bolivian Altiplano. Journal of Quaternary Science 12, 169-182.

Denton, G.H., Lowell, T.V., Heusser, C.J., Schlüchter, C., Andersen, B.G., Heusser, L.E., Moreno, P.I., Marchant, D.R. 1999. Geomorphology, stratigraphy, and radiocarbon chronology of Llanquihue drift in the area of the southern Lake District, Seno Reloncavi, and Isla Grande de Chiloe, Chile. Geografiska Annaler 81A, 167-229. http://doi.org/10.1111/1468-0459.00057.

Espizua, L.E. 2004. Pleistocene glaciations in the Mendoza Andes, Argentina. In: J. Ehlers, P.L. Gibbard (Eds.), Quaternary Glaciations - Extent and Chronology. Part III: South America, Asia, Africa, Australasia, Antarctica. Cambridge, Elsevier.

Farber, D.L., Hancock, G.S., Finkel, R.C., Rodbell, D.T. 2005. The age and extent of tropical alpine glaciation in the Cordillera Blanca, Peru. Journal of Quaternary Science 20, 759-776. http:// doi.org/10.1002/jqs. 994 .

Garreaud, R., Aceituno, P. 2001. Interannual Rainfall Variability over the South American Altiplano. Journal of Climate 14 (12), 2779-2789.

Garreaud, R., Aceituno, P. 2007. Atmospheric circulation and climatic variability. In: T.T. Veblen, K.R. Young, A.R. Orme (Eds.) The physical geography of South America. Oxford University Press, Oxford.

Garreaud,R.,Vuille,M.,Clement,A.C. 2003. The climate of the Altiplano: observed current conditions and mechanisms of past changes. Palaeogeography, Palaeoclimatology, Palaeoecology 194 1-3, 5-22. http://doi.org/10.1016/S0031-0182(03)00269-4. 
Garreaud, R.D., Vuille, M., Compagnucci, R., Marengo, J. 2009. Present-day South American climate. Palaeogeography, Palaeoclimatology, Palaeoecology 281 (3-4), 180-195. http://doi. org/10.1016/j.palaeo.2007.10.032.

Haselton, K., Hilley, G, Strecker, M.R. 2002. Average Pleistocene Climatic Patterns in the Southern Central Andes: Controls on Mountain Glaciation and Paleoclimate Implications. The Journal of Geology 110 (2), 211-226. http://doi.org/10.1086/338414.

Heinrich, H. 1988. Origin and consequences of cyclic ice rafting in the Northeast Atlantic Ocean during the past 130,000 years. Quaternary Research 29 (2), 142-152. http://doi.org/10.1016/00335894(88)90057-9.

Hemming, S.R. 2004. Heinrich Events: Massive late Pleistocene detritus layers of the North Atlantic and their global climate imprint. Reviews of Geophysics 42, RG1005. http://doi. org/10.1029/2003RG000128.

Heyman, J., Stroeven, A.P., Harbor, J.M., Caffee, M.W. 2011. Too young or too old: Evaluating cosmogenic exposure dating based on an analysis of compiled boulder exposure ages. Earth and Planetary Science Letters 302 (1-2), 71-80. http://doi.org/10.1016/j.eps1.2010.11.040.

Kaiser, J., Lamy, F., Hebbeln, D. 2005. A 70-kyr sea surface temperature record off southern Chile (Ocean Drilling Program Site 1233). Paleoceanography 20 (4), PA4009. http://doi. org/10.1029/2005PA001146.

Kaiser, J., Schefuß, E., Lamy, F., Mohtadi, M., Hebbeln, D. 2008. Glacial to Holocene changes in sea surface temperature and coastal vegetation in north central Chile: high versus low latitude forcing. Quaternary Science Reviews 27, 2064-2075. http://doi.org/10.1016/j.quascirev.2008.08.025.

Kienast, M., Kienast, S.S., Calvert, S.E., Eglington, T.I., Mollenhauer, G., Francois, R., Mix, A.C. 2006. Eastern Pacific cooling and Atlantic overturning circulation during the last deglaciation. Nature 443, 846-849. http://doi.org/10.1038/nature05222.

Kubik, P.W., Christl, M. 2010. ${ }^{10} \mathrm{Be}$ and ${ }^{26} \mathrm{Al}$ measurements at the Zurich 6 MV Tandem AMS facility. Nuclear Instruments and Methods in Physics Research B Beam Interactions with Materials and Atoms 268 (7-8), 880-883. http://doi.org/10.1016/j.nimb.2009.10.054.

Korschinek, G., Bergmaier, A., Faestermann, T., Gerstmann, U.C., Knie, K., Rugel, G., Wallner, A., Dillmann, I., Dollinger, G., von Gostomski, C.L., Kossert, K., Maiti, M., Poutivtsev, M., Remmert, A. 2010. A new value for the half-life of ${ }^{10} \mathrm{Be}$ by Heavy-Ion Elastic Recoil Detection and liquid scintillation counting. Nuclear Instruments and Methods in Physics Research Section B: Beam Interactions with Materials and Atoms 268 (2), 187-191. http://doi.org/10.1016/j.nimb.2009.09.020.

Kull, C., Grosjean, M. Veit, H. 2002. Modeling Modern and Late Pleistocene Glacio-Climatological Conditions in the North Chilean Andes (29-30 $)$. Climatic Change 52, 359-381. http://doi. org/10.1023/A:1013746917257.

Kull, C., Imhof, S., Grosjean, M., Zech, R., and Veit, H. 2008. Late Pleistocene glaciation in the Central Andes: Temperature versus humidity control - A case study from the eastern Bolivian Andes $\left(17^{\circ} \mathrm{S}\right)$ and regional synthesis. Global and Planetary Change 60, 148-164. http://doi. org/10.1016/j.gloplacha.2007.03.011

Lamy, F., Hebbeln, D., Wefer, G. 1999. High-Resolution Marine Record of Climatic Change in Mid-latitude Chile during the Last 28,000 Years Based on Terrigenous Sediment Parameters. Quaternary Research 51 (1), 83-93.

Latorre, C., Betancourt, J.L., Arroyo, M.T.K. 2006. Late Quaternary vegetation and climate history of a perennial river canyon in the Rio Salado basin $\left(22^{\circ} \mathrm{S}\right)$ of Northern Chile. Quaternary Research 65 (3), 450-466. http://doi.org/10.1016/j.yqures.2006.02.002.

Lifton, N., Sato, T., Dunai, T.J. 2014. Scaling in situ cosmogenic nuclide production rates using analytical approximations to atmospheric cosmic-ray fluxes. Earth and Planetary Science Letters 386, 149-160. http://doi.org/10.1016/j.eps1.2013.10.052.

Lowell, T.V., Heusser, C.J., Andersen, B.G., Moreno, P.I., Hauser, A., Heusser, L.E., Schlüchter, C., Marchant, D.R., Denton, G.H. 1995. Interhemispheric correlations of Late Pleistocene glacial events. Science 269, 1541-1549. http://doi.org/10.1126/science.269.5230.1541. 
Maldonado, A., Betancourt, J.L., Latorre, C., Villagran, C. 2005. Pollen analyses from a 50,000yr rodent midden series in the southern Atacama Desert (25 30' S). Journal of Quaternary Science 20 (5), 493-507. http://doi.org/10.1002/jqs.936.

Marrero, S.M., Phillips, F.M., Borchers, B., Lifton, N., Aumer, R., Balco, G. 2016. Cosmogenic nuclide systematics and the CRONUScalc program. Quaternary Geochronology 31, 160-187.

May, J.-H., Zech, J., Zech, R., Preusser, F., Argollo, J., Kubik, P., Veit, H. 2011. Reconstruction of a complex late Quaternary glacial landscape in the Cordillera de Cochabamba (Bolivia) based on a morphostratigraphic and multiple dating approach. Quarternary Research 76, 106-118. http:// doi.org/10.1016/j.yqres.2011.05.003.

Moreiras, S.M., Páez, M.S., Lauro, C., Jeanneret, P. 2016. First cosmogenic ages for glacial deposits from the Plata range $\left(33^{\circ} \mathrm{S}\right)$ : New inferences for Quaternary landscape evolution in the Central Andes. Quaternary International 438, 50-64, http://dx.doi.org/10.1016/j.quaint.2016.08.041.

Peltier, W.R., Fairbanks, R.G. 2006. Global glacial ice volume and Last Glacial Maximum duration from an extended Barbados sea level record. Quaternary Science Reviews 25, 3322-3337. http://doi.org/10.1016/j.quascirev.2006.04.010.

Phillips, F.M., Argento, D.C., Balco, G., Caffee, M.W., Clem, J., Dunai, T.J., Finkel, R., Goehring, B., Gosse, J.C., Hudson, A.M., Jull, A.J.T., Kelly, M.A., Kurz, M., Lal, D., Lifton, N., Marrero, S.M., Nishiizumi, K., Reedy, R.C., Schaefer, J., Stone, J.O.H., Swanson, T., and Zreda, M.G. 2016. The CRONUS-Earth Project: A Synthesis, Quaternary Geochronology 31, 119-154. http://doi.org/10.1016/j.quageo.2015.09.006.

Placzek, C., Quade, J., Patchett, J.P. 2006. Geochronology and stratigraphy of late Pleistocene lakes cycles on the southern Bolivian Altiplano: Implications for causes of tropical climate change. Geological Society of America Bulletin 118, 515-532.

Placzek, C., Quade, J., Patchett, P.J. 2011. Isotopic tracers of paleohydrologic change in large lakes of the Bolivian Altiplano. Quaternary Research 75 (1), 231-244. http://doi.org/10.1016/j. yqres.2010.08.004.

Putkonen, J. Swanson, T. 2003. Accuracy of cosmogenic ages for moraines. Quarternary Research 59, 255-261. http://doi.org/10.1016/S0033-5894(03)00006-1.

Quade, J., Rech, J.A., Betancourt, J.L., Latorre, C., Quade, B., Rylander, K.A., Fisher, T. 2008. Paleowetlands and regional climate change in the central Atacama Desert, northern Chile. Quaternary Research 69 (3), 343-360. http://doi.org/10.1016/j.yqres.2008.01.003.

Riquelme, R., Rojas, C., Aguilar, G., Flores, P. 2011. Late Pleistocene-early Holocene paraglacial and fluvial sediment history in the Turbio valley, semiarid Chilean Andes. Quaternary Research 75 (1), 166-175. http://doi.org/10.1016/j.yqres.2010.10.001 .

Rodbell, D.T., Smith, J.A., Mark, B.G. 2009. Glaciation in the Andes during the Lateglacial and Holocene. Quaternary Science Reviews 28, 2165-2212. http://doi.org/10.1016/j. quascirev.2009.03.012.

Sáez, A., Valero-Garcés, B.L., Giralt, S., Moreno, A., Bao, R., Pueyo, J.J., Hernández, A., Casas, D. 2009. Glacial to Holocene climate changes in the SE Pacific. The Raraku Lake sedimentary record (Easter Island, 27 ${ }^{\circ}$ S). Quaternary Science Reviews 28 (25-26), 2743-2759. http://doi. org/10.1016/j.quascirev.2009.06.018.

Shakun, J.D., Clark, P.U., He, F., Lifton, N.A., Liu, Z., Otto-Bliesner, B.L. 2015. Regional and global forcing of glacier retreat during the last deglaciation. Nature Communications 6, 8059. http:// doi.org/10.1038/ncomms9059.

Smith, C.A., Lowell, T.V., Owen, L.A., Caffee, M.W. 2011. Late Quaternary glacial chronology on Nevado Illimani, Bolivia, and the implications for paleoclimatic reconstructions across the Andes. Quaternary Research 75 (1), 1-10. http://doi.org/10.1016/j.yqres.2010.07.001.

Terrizzano, C., Zech, R., García Morabito, E., Haghipour, N., Christl, M., Likermann, J., Tobal, J., Yamin, M. 2016. Surface exposure dating of moraines and alluvial fans in the Southern Central Andes. Geophysical Research Abstracts, 18, EGU2016-15358. 
Tripaldi, A., Forman, S.L. 2016. Eolian depositional phases during the past $50 \mathrm{ka}$ and inferred climate variability for the Pampean Sand Sea, western Pampas, Argentina. Quaternary Science Reviews 139, 77-93. http://doi.org/10.1016/j.quascirev.2016.03.007.

Valero-Garcés, B.L., Jenny, B., Rondanelli, M., Delgado-Huertas, A., Burns, S.J., Veit, H., Moreno, A. 2005. Palaeohydrology of Laguna de Tagua Tagua ( $34^{\circ} 30^{\prime} \mathrm{S}$ ) and moisture fluctuations in Central Chile for the last 46000 yr. Journal of Quaternary Science 20 (7-8), 625-641. http:// doi.org/10.1002/jqs.988.

Veit, H., May, J-H., Madella, A., Delunel, R., Schlunegger, F., Szidat, S., Capriles, J.M. 2016. Palaeogeoecological significance of Pleistocene trees in the Lluta Valley, Atacama Desert. Journal of Quaternary Science 31 (3), 203-213. http://doi.org/10.1002/jqs.2857.

Vuille, M. Ammann, C. 1997. Regional snowfall patterns in the high, arid Andes (South America). Climatic Change 36, 413-423. http://doi.org/10.1023/A:1005330802974.

Vuille, M., Bradley, R.S., Keimig, F. 2000. Interannual climate variability in the Central Andes and its relation to tropical Pacific and Atlantic forcing. Journal of Geophysical Research 105 D10, 12447-12460. http://doi.org/10.1029/2000JD900134.

Vuille, M., Keimig, F. 2004. Interannual variability of summertime convective cloudiness and precipitation in the Central Andes derived from ISCCP-B3 Data. Journal of Climate 17, 33343348. http://doi.org/10.1175/1520-0442(2004)017<3334:IVOSCC>2.0.CO;2.

Wäger, P. 2009. Glacier-climate modelling in Las Leñas, Central Andes of Argentina. Master Thesis, Faculty of Sciences, University of Bern, 135 pp.

Zech, J., Zech, R., Kubik, P.W., Veit, H. 2009. Glacier and climate reconstruction at Tres Lagunas, NW Argentina, based on 10Be surface exposure dating and lake sediment analyses. Palaeogeography, Palaeoclimatology, Palaeoecology 284, 180-190. http://doi.org/10.1016/j. palaeo.2009.09.23

Zech, R., Glaser, B., Sosin, P., Kubik, P.W., Zech, W. 2005. Evidence for long-lasting landform surface instability on hummocky moraines in the Pamir Mountains (Tajikistan) from 10Be surface exposure dating. Earth and Planetary Science Letters 237 (3-4), 453-461. http://doi. org/10.1016/j.epsl.2005.06.31.

Zech, R., Kull, C., Kubik, P.W., Veit, H. 2007. LGM and Late Glacial glacier advances in the Cordillera Real and Cochabamba (Bolivia) deduced from 10Be surface exposure dating. Climate of the Past 3, 623-635.

Zech, R., May, J.-H., Kull, C., Ilgner, J., Kubik, P.W., Veit, H. 2008. Timing of the late Quaternary glaciation in the Andes from $\sim 15$ to $40^{\circ}$ S. Journal of Quaternary Science 23, 635-647. http:// doi.org/10.1002/jqs.1200.

Zech, R., Smith, J., Kaplan, M. 2009. Chronologies of the LGM and its Termination in the Andes based on Surface Exposure Dating. In: F. Vimeux, F. Sylvestre, M. Khodri (Eds.), Past climate variability in South America and surrounding regions. From the Last Glacial Maximum to the Holocene. Springer, pp. 61-87.

Zhou, J., Lau, K.M. 1998. Does a monsoon climate exist over South America? Journal of Climate $11,1020-1040$.

Zreda, M., Clapperton, C., Argollo, J., Shanahan, T. 2001. Evidence for contemporary lakes and glaciers in the southern Altiplano during late glacial time. Fifth Iberian Quaternary Meeting (extended abstract), Lisboa, Portugal. 